\title{
渋滞の延伸を考慮した マルコフ連鎖による動的利用者均衡配分
}

\author{
福田 和輝 1 -井料 隆雅 2 - 浦田 淳司 3 - 石原 雅晃 4 \\ 1学生会員 神戸大学 大学院工学研究科市民工学専攻（†657-8501 神戸市灘区六甲台町1-1） \\ E-mail: 163t130t@stu.kobe-u.ac.jp \\ 2正会員 神戸大学大学院教授 工学研究科市民工学専攻（†657-8501 神戸市灘区六甲台町1-1） \\ E-mail: iryo@kobe-u.ac.jp \\ 3 正会員 神戸大学大学院 工学研究科市民工学専攻（广 657-8501 神戸市灘区六甲台町1-1） \\ E-mail: urata@person.kobe-u.ac.jp \\ 4正会員 阪神高速道路株式会社（广541-0056 大阪市中央区久太郎町4-1-3） \\ E-mail: masaaki-ishihara@hanshin-exp.co.jp
}

\begin{abstract}
動的利用者均衡配分問題において, 交通流パターンの日々の調整過程であるDay-to-dayダイナミクスを 離散マルコフ連鎖で記述することで，均衡解あるいはそれに近い定常状態を求める方法が提案されている. しかし, 既存研究では渋滞の延伸を考慮した交通流モデルは用いられていなかった。本研究では, 渋滞の 延伸が考慮できるモデルを適用して同様の計算を行う方法を構築し，テストネットワークに対して既存研 究と同様な配分計算を行った。計算の結果，交通量が比較的少ない場合には渋滞の延伸を考慮した交通流 モデルを用いた場合でも，日々の交通状況が定常とみられる状態に到達寸ることが明らかとなった。また， その渋滞パターンは延伸がない場合と異なっており，渋滞の延伸を考慮することがより正しい混雑の評価 のために必要であることを明らかにした。
\end{abstract}

Key Words : dynamic user equilibrium, traffic assignment, day-to-day dynamics, physical queue

\section{1. はじめに}

道路交通ネットワークの混雑を評価する手法の一つに 動的利用者均衡配分（DUE）がある．DUEにおいては すべてのドライバーが実際に経験する旅行時間が最小に なるように交通量を動的に配分する。これまで様々なア プローチの解法が提案されている．例えば，Kuwahara and Akamatsu1は均衡状態であれば同時刻に出発する車 両は必ず同時刻に各ノードに達することを利用し出発時 刻で分割する方法による解法を提案している．また，井 料2は，車両を離散化して均衡状態をNash均衡により定 義した解法を提案している.

一般に，均衡配分問題の解は，解の存在，一意性，安 定性, そして, 必ず解を導出できる解法の存在といった 特性を満足することが望ましい． Iryo ${ }^{31}$ は，これまでに 行われた動的利用者均衡配分に関寸る研究についてレビ ューを行い，動的利用者均衡配分問題において，均衡解 の存在は保証されるが，他の特性は限定的な状況下以外 では保証されないことを示している.
均衡解を厳密に求めることができない場合の代案とし て考えられるのが，ドライバーの経路選択の日々の調整 過程（Day-to-dayダイナミクス）をマルコフ連鎖によ り記述し, 定常分布を求め, それを均衡解に代えて解と する方法である. 石原・井料(4)石原ら 路選択を前提としたDay-to-day ダイナミクスを動的交 通量配分の解法として提案している。 これらの解法では, 車両を離散化し，1日に1台の車両，あるいは複数の車 両がランダムに選択され，その時点の交通状態に応じて 経路を選択しなおすという Day-to-dayダイナミクスを 用いている. 石原ら5゙では, Sioux Falls Network'五を対 象とした数值計算において, 交通状態の日々の恋化の定 常性を示唆する結果を算出している. しかし，これらの 研究では，あるリンクで発生した渋滞の影響が他のリン クに影響を与えない（啮滞の延伸を考慮しない）交通流 モデルを用いている，一方で，渋滞が交差点を越えて延 伸する現象は，現実交通においても多々発生し，多くの 車両がその影響を被ることが知られている．そのため, 渋滞の延伸を考慮しないことによる現実の交通現象との 
乘離が問題視される.

渋滞の延伸を考慮できる交通流モデルを用いてDUE を解くことは過去にも試みられている，例えば，Lo and Szeto7)は，動的な交通流モデルとしてCTM（Cell Transmission Model）を採用した変分不等式によるア プローチを提案している. しかし，この方法は解を必ず 導出できるとは限らない，実際，この論文の中では，解 の収束過程が単調にはならなかったケースが紹介されて いる.

本研究では，Day-to-dayダイナミクスを計算するこ とで交通状態の定常状態を算出するマルコフ連鎖による 解法に着目し, 既往研究4),5)で考慮していない渋帯の延伸 を交通流モデルに導入し，日々の交通状態の変化の定常 性を確認することでマルコフ連鎖を用いた解法の妥当性 を評価することを目的とする．併せて，淽滞の延伸が交 通状態に与える影響も評価する．まず，既往研究では考 慮していない渋帯の延伸を交通流モデルに導入し，石原 ら5) と同様に「1日に複数台の車両が前日の交通状態を 基に経路変更を行う」というDay-to-dayダイナミクス を定式化, 計算する. その結果, 既往研究と同様に日々 の交通状態が定常とみられる状態に到達するかを確かめ る. 次に，本来の交通流をより正確に再現できる渋滞の 延伸を考慮した場合と考慮しなかった場合で，ネットワ 一ク上での遅れ時間にどのような違いがあるかを確かめ る.

\section{2. 交通流モデル}

\section{(1) 定式化}

有向リンクとノードにより構成される交通ネットワー クを考える。ノード集合を $V$, リンク集合を $E$ し，各 ノードを $n_{1}, n_{2}, \ldots, n_{p} \in V$ で，各リンクを $l_{1}, l_{2}, \ldots, l_{q} \in E$ で 表す.

車両は離散的なものとして扱う。車両の集合を $N$ ，そ の台数を $\mid N$ とする. 車両 $i \in N$ には，あらかじめ起点ノ 一ド $o_{i}$, 終点ノード $d_{i}$, 起点出発時刻 $\tau_{i}$, そして経路 $r_{i}$ を与える。車両 $i$ が $o_{i}$ から $d_{i}$ までノード $n_{1}, n_{2}, \ldots, n_{k} \in V$ をこの順番で経由するとき, 経路 $r_{i}$ を $r_{i}=\left(n_{1}, n_{2}, \ldots, n_{k}\right)$ と表す.

\section{（2）交通流モデル}

\section{a) ボトルネックモデル}

リンクの遅れ時間の評価には，石原・井料4)と同様に ボトルネックモデルを用いる. 車両 $i \in N$ のリンク $l \in E \sim の$ 流入時刻と流出時刻をそれぞれ $t_{i}(l), u_{i}(l)$ と する.また，リンク $l$ に自由流旅行時間 $f(l)$ と最小へ
ツドウェイ $h(l)$ を与える. 車両 $i, j \in N$ がリンク $l$ に流 入する車両であるとし，車両 $i$ の前方には車が存在せず， 車両 $i$ の次に車両 $j$ が流入する場合, 各車両の流出時刻 $u_{i}(l), u_{j}(l)$ は,

$$
\begin{aligned}
& u_{i}(l)=t_{i}(l)+f(l) \\
& u_{j}(l)=\left\{\begin{array}{lcc}
t_{j}(l)+f(l) & \text { if } & t_{j}(l)-t_{i}(l) \geq h(l) \\
u_{i}(l)+h(l) & & \text { otherwise }
\end{array}\right.
\end{aligned}
$$

となる。

\section{b) 渋滞の延伸モデル}

本研究では，各リンクに帯留可能台数を新たに導入す ることで淽帯の延伸を評価する. ある車両が現在のリン クを流出しようとするときに，その車両が次に流入する リンクの車両台数とそのリンクの帯留可能台数を比較し て流入可否を判断する. 流入不可の場合は, そのリンク に車両が流入できる空間が生じる時刻に流出時刻を更新 する.このモデルの導入により, 既往研究4),5では考慮し ていない渋滞の延伸が交通流に与える影響を評価できる.

\section{c) 合流の優先権}

交通流モデルに渋帯の延伸を導入するにあたり，渋滞 がリンクの下流側から上流側の交差点まで延伸した場合 に，その交差点の上流側の異なるリンクで待つ車両の流 入順序を決める必要がある. 本研究では, リンクの先頭 車両となった時刻が早い順に優先権を与える.

\section{3. 配分計算}

\section{（1）旅行時間の算出方法}

本研究では，石原・井料 4) と同様に，車両は一日前の 交通状態に基づいて最短経路を確定的に選択するとする 最短経路探索は Dijkstra 法により行うため, リンク旅 行時間の取得が必要である. 本研究では, 渋滞の延伸の 導入にあたり，下流側のリンクから延伸する渋滞を考慮 してリンク旅行時間を決定するアルゴリズムを構築する. ここでは, 時刻 $t$ でリンク $l$ に流入した車両が, リンク $l$ を流出するまでに要する時間をリンク旅行時間とする. この旅行時間は，他車に影響を一切及ぼさない仮想的な 車両（仮想車両） $v$ をリンクに実際に走行させることに より算出する. 具体的な算出方法は以下の通り：

Step1: ある時刻 $t\left(=t_{v}(l)\right)$ に仮想車両 $v$ をリンク $l$ に流入 させ，流出時刻 $u_{v}(l)$ を，仮にリンク $l$ の自由流旅 行時間 $f(l)$ を用いて以下の式で計算する.

$$
u_{v}(l)=t_{v}(l)+f(l)
$$

Step2: リンク上に先行車両 $p$ が存在するとき, この仮想 車両 $v$ は先行車両 $p$ が流出するまで流出できない とし, Step3へ移る. 先行車両 $p$ が存在しないとき, 
Step4几移る.

Step3: 先行車両 $p$ がリンク $l$ を流出した時刻 $u_{p}(l)$ とStep1 で算出した仮想車両の流出時刻 $u_{v}(l)$ からへッドウ エイ $h$ を以下の式で計算し, リンクの最小ヘッド ウェイ $h(l)$ との比較を行う. 最小ヘッドウェイ未 満のとき仮想車両の流出時刻 $u_{v}(l)$ を更新する.

Step4几移る.

$$
\begin{aligned}
& h=u_{v}(l)-u_{p}(l) \\
& u_{v}(l)=\left\{\begin{array}{cc}
u_{v}(l) & \text { if } \quad h \geq h(l) \\
u_{p}(l)+h(l) & \text { otherwise }
\end{array}\right.
\end{aligned}
$$

Step4: 流出判定を行う．計算された仮想車両の流出時刻 $u_{v}(l)$ の時点で, 下流端ノードから伸びる全リンク に対して，仮想車両の流出可否を以下の条件で判 定する。

$$
\begin{aligned}
& N_{l_{d}, u_{v}(l)}<C_{l_{d}} \\
& t_{\text {precar }}\left(l_{d}\right)-u_{v}(l) \geq h\left(l_{d}\right)
\end{aligned}
$$

ここに， $l_{d}$ は下流端ノードから伸びるリンク， $N_{l, u}$ はある時刻 $u$ におけるリンクlの滞留台数, $C_{l}$ はリンク $l$ の最大滞留可能台数, $t_{\text {prear }}(l)$ はリ ンク $l$ の最後尾車両の流入時刻とする. この条件 を満足するとき， $u_{v}(l)$ を仮想車両の流出時刻と する，一方で，流入不可であれば，以下の条件 を用いて車両の流出時刻を流入可能となる時刻 で更新する。

$\begin{cases}u_{v}(l)=u_{\text {frontar }}\left(l_{d}\right) & \text { if } N_{l_{d}, u_{v}(l)}=C_{l_{d}} \\ u_{v}(l)=t_{\text {precar }}\left(l_{d}\right)+h\left(l_{d}\right) & \text { if } t_{\text {precar }}\left(l_{d}\right)-u_{v}(l)<h\left(1_{d}\right)\end{cases}$

ここに, $u_{\text {frontcar }}(l)$ はリンク $l$ の先頭車両の流出 時刻とする。もし，下流端ノードから伸びる複 数のリンクで流出不可と判定された場合は，流 出可能となる時刻の中で, 最も遅い時刻を仮想 車両の流出時刻とする．仮想車両の流出時刻が 確定したとき，その時刻 $u_{v}(l)$ から流入時刻 $t_{v}(l)$ を差し引いてリンク旅行時間を求める. また,

下流端ノードから下流側にリンクが伸びていな い場合は，仮想車両はStep3までに計算された流 出時刻 $u_{v}(l)$ で必ず流出できるものとする.

Dijkstra 法による最短経路探索では, リンク旅行時 間はリンクごとに一意の值である必要がある，下流端～ ードから複数のリンクが伸びているとき, 少なくとも 1 本のリンクで渋滞が延伸し，そのリンクへ流入する車両 のみがその影響を受けるとすると, リンク旅行時間が複 数生じてしまう。この場合, リンク旅行時間が一意に定 まらず，Dijkstra 法が実行できない．Dijkstra 法を実行

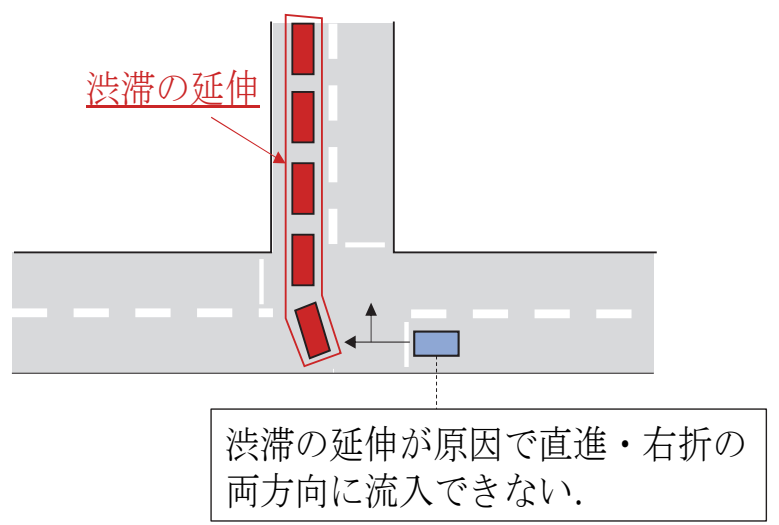

図-1＼cjkstart旅行時間算出方法における渋滞の延伸の想定

するために，Step4 では，「下流端ノードから伸びる全 てのリンクの流入可能時刻のうち最も遅い時刻で旅行時 間を一意に決定する」という方法を用いている。これは, 下流側のあるリンクで生じた渋滞が現在のリンクの下流 端ノードまで延伸しているとき，他の下流側のリンクへ の車両の流出もその啮滞によって制限される状況である. 実現象に照らせば，図-1 に示寸ように，ある道路で生 じた渋滞が上流側の交差点まで延伸した場合に，その交 差点内に茨滞列の車両が滞留する．このとき，その交差 点に流入しょうとする車両は, 行先が渋滞している道路 と異なる方向であっても, 交差点内の車両が移動するま で流入できない，下流側のリンクから渋滞が延伸してい る場合のリンク旅行時間の算出方法（Step4）は，この 実現象と対応している. また, 渋滞の延伸を考慮するこ とで, 最短経路探索において起点ノード費用（本研究で は，車両が起点ノードからリンクに流入する時刻とす る）が一意に定まらないという問題が生じるが，この問 題の解決法は 3.(2)で述べる.

\section{（2）最短経路探索における起点ノード費用の決定に関 する問題点とその解決法}

Dijkstra法による最短経路探索では，渋滞の延伸を考 慮した交通流モデルを用いることで，起点ノード費用を 一意に決められない場合がある. 本研究では, Dijkstra 法において，車両がノードに到着する時刻をそのノード の費用として与える. その費用に基づいて下流側の各リ ンクの旅行時間を3.(1)の方法で算出し，そのリンクの下 流端ノードの費用を求める. この計算過程を繰り返し, 最短経路を探索する. 起点ノードの費用についても, 車 両が起点から下流側のリンクに実際に流入する時刻を与 えることで，そのリンクの旅行時間を算出することがで きる．しかし，渋滞の延伸を考慮すると，車両はあらか じめ与えられた出発時刻に下流側のリンク全てに流入で きるとは限らない. ある下流側のリンクから啮滞が起点 ノードまで延伸している場合は，車両の出発時刻にその 
(ア)

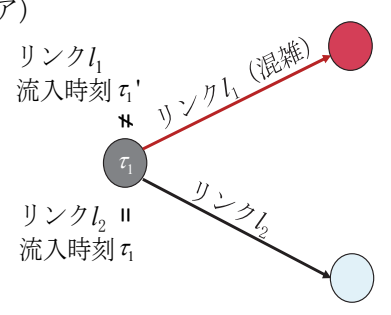

(イ)

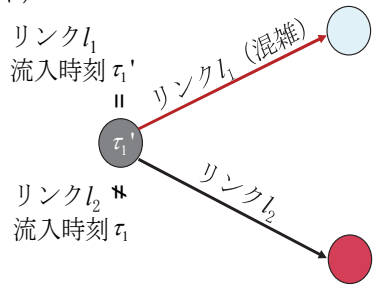

x) :起点ノード費用 $x$

：ノード費用が正しく計算されているノード

：ノード費用が正しく計算されていないノード

図-2 最短経路探索における問題点

リンクには流入できず，そのリンクに流入可能な時刻は 出発時刻よりも遅くなる。具体的には図-2の場合である. 「車両1は出発時刻 $\tau_{1}$ に起点ノードを出発するが，リン ク $l_{1}$ で泣滞が発生しリンク $l_{1}$ の上流端まで渋滞列が伸び ている場合，リンク $l_{1}$ には時刻 $\tau_{1}$ で流入することができ ない．このとき，この車両がリンク $l_{1}$ に流入できる時刻 はリンク $l_{1}$ の先頭車両が当該リンクを流出した時刻 $\tau_{1}{ }^{\prime}\left(>\tau_{1}\right)$ となる. 一方, リンク $l_{2}$ は混雑しておらず，車 両 1 は出発時刻 $\tau_{1}$ と同時刻 $\tau_{1}$ でリンク $l_{2}$ に流入できる」 という場合である. この場合，起点ノードから伸びる下 流側のリンクごとに実際に流入できる時刻が異なるため, それぞれのリンクの旅行時間を算出するには，起点ノー ドの費用として複数の時刻を考慮しなければならない. したがって，起点ノードの費用を一意に決定することが できず，渋滞の延伸を考慮する場合は，従来のネットワ 一ク構造を用いてDijkstra法を実行することができない 例えば，図-2において，2つの異なる流入可能時刻が存 在する場合，（ア）のようにリンク $l_{2}$ への流入時刻を起 点ノードの費用と設定すると, リンク $l_{2}$ の下流側のノー ド費用は正しく計算されるが，リンク $l_{1}$ の下流側のノー ド費用は正しく計算されない，また，（イ）のように起 点ノードの費用をリンク $l_{1}$ への流入時刻で設定した場合 は逆に，リンク $l_{1}$ の下流側のノード費用は正しく計算さ れるが，リンク $l_{2}$ の下流側のノード費用は正しく計算さ れない。

Dijkstra法において，起点ノードから伸びる下流側の リンクで異なる車両の流入時刻は個別に考慮されるべき である. 図-3に示すように，出発地（パーキング等）か らの車両の流入を考える場合，その車両は道路上を走行 していないので，ある道路に流入するとき，他の道路の 渋滞の影響を受けるべきではない. したがって，最短経 路探索において, 起点ノードから各下流側のリンクへの 異なる流入時刻を個別に考慮することが望ましい．しか し，Dijkstra法を適用する場合には，起点ノードの費用 を一意に決定することは必須である。この両者の要求を 同時に満足する方法が必要となる.

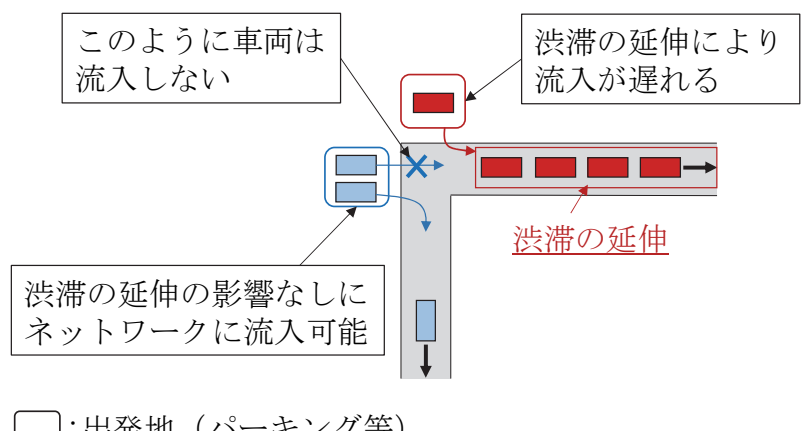

図-3 起点ノードからの流入の考え方

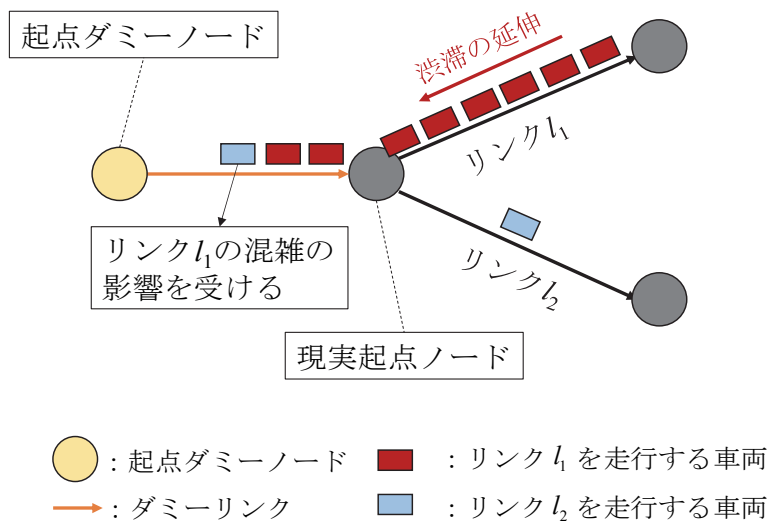

図-4 ネットワーク構造の改良（その 1)

この問題を解決する方法として，ダミーノードとダミ ーリンクを起点ノードの上流側に1組生成し，車両の起 点での遅れ時間をそのダミーリンクでの遅れ時間として 評価する方法が考えられる（図-4）。本研究で扱うダミ ーリンクは, ヘッドウェイと滞留可能台数に制約をもた ず，下流側のリンクに混雑がない場合，旅行時間0秒で 通過することができるリンクとしている，車両は，生成 したダミーノードを新たな起点としてあらかじめ与えら れた出発時刻に必ずダミーリンクに流入する．そのため, 起点ノードの費用を車両の出発時刻で一意に決めること ができる.しかし，同一の起点ノードから出発する車両 すべてを同じダミーリンクに流入させるため，図-4の場 合を考えると, 混雑していないリンク $l_{2}$ に流入する車両 がリンク $l_{1}$ の混雑の影響をダミーリンクで被ってしまい, 流入するリンクごとに遅れ時間を正しく評価できない. そのため，この方法では不十分であるといえる.

本研究では，ネットワークの構造を変化させることで, 起点ノードから各リンクへの異なる流入時刻を考慮した 上で，起点ノードの費用も一意に決定できる方法を提案 する．具体には，車両の起点となるノードに対して，そ れぞれダミーノードとダミーリンクを図-5のように生成 したネットワーク構造を導入する. 車両は本来の起点ノ 一ドに変えて起点ダミーノードから出発し，リンク $l_{1}$ を 走行寸る車両については, ダミーリンク $D_{l_{1}}$ に流入し, ダミーノードを経由してリンク $l_{1}$ に流入できる（本来の 


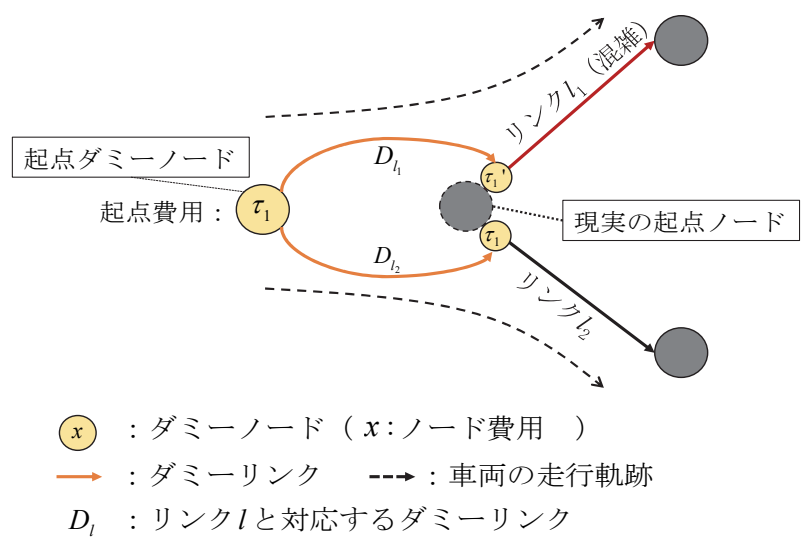

図-5 ネットワーク構造の改良（その2）

起点ノードは経由しない）。それ以降，現実のネットワ ーク上を目的地に到達するまで走行する. 同様に, リン ク $l_{2}$ を走行する車両については, ダミーリンク $D_{l}$ に流 入し，ダミーノードを経由してリンク $l_{2}$ に流入できる. ダミーリンクから現実のリンクへの流出判定は2章で説 明した方法により行う。また，流入する現実のリンクの 上流端ノード（起点ノード）まで渋滞が延伸しており， さらに，起点ノードの上流側に他の現実リンクがある場 合は, 交通流モデル (2.(2)c)）に従い, そのリンクとダ ミーリンクで合流の問題を考える. 生成したダミーリン クとダミーノードは, 対応関係にある起点ノードを出発

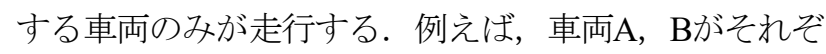
れ異なる起点ノードから出発する場合, 車両Bは, 車両 $\mathrm{A}$ の起点ノードに対して生成されたダミーリンクとダミ 一ノードを走行せず，また，最短経路探索においても計 算対象としない. このネットワーク構造を用いることで, 各リンク $l_{1}, l_{2}$ の混雑が原因で発生する異なる起点での 遅れ時間を対応するダミーリンク $D_{l_{1}}, D_{l_{2}}$ での遅れ時 間として別々に考慮することができる，これにより，最 短経路探索において起点ノード費用を一意に決めること ができる．このネットワーク構造にDijkstra法を適用す る際には，図-5に示すようにその車両の本来の起点ノー ドは計算対象とせず，代わりに生成したダミーノードの 費用を計算し，最短経路を探索する.

起点ダミーノード以外で単にノード（起点ダミーノー ド以外のダミーノードを含む) を経由する場合のリンク の流出時刻の計算方法は, 交通流の計算と最短経路探索 で異なる．交通流の計算では，車両の経路が特定できる ため, リンクの下流端ノードへ流入しようとする場合に は, 次に流入するリンクの渋滞のみを考慮して, 流出時 刻を計算する（2章の交通流モデルに基づく）。一方で, 最短経路探索においては, 経路が特定できないため, 下 流側のリンクを特定して流出時刻を計算できない，この 対処法として，3.(1)図-1で示した状況が起こると想定し，
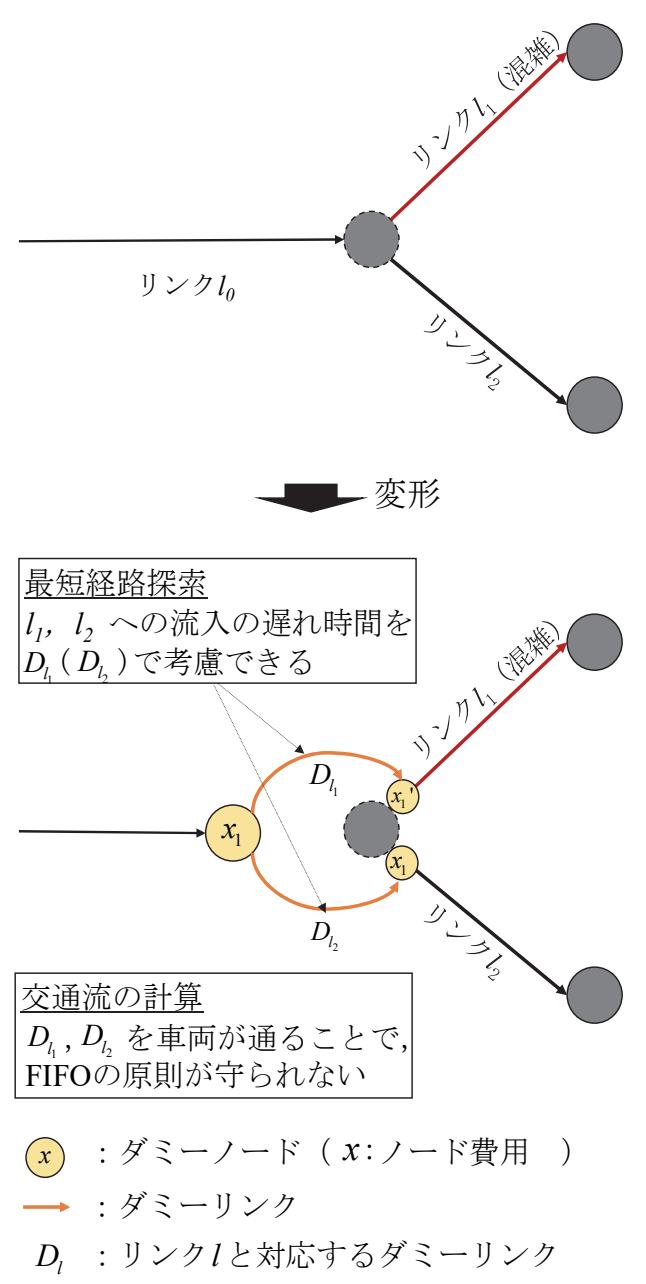

図-6 経由ノードに改良を行った場合の利点と欠点

下流端ノードから伸びるリンクへの流入可能時刻の中で 最も遅い時刻に, 車両がその下流端ノードに流出できる とすることで，リンクの旅行時間を定めている．ただし， 後者については, 図-6に示すように, 起点ノード以外の ノードにおいて，図-5と同様にネットワーク構造を変化 させることで, 各下流リンクの渋滞を個別に考慮してリ ンク旅行時間を算出し, 最短経路探索を行うことができ る. ダミーノードの費用 $x_{1}$ は, リンク $l_{0}$ において, 下 流側のリンク $l_{1}, l_{2}$ の混雑を考慮しなかった場合の車両 の流出時刻である（3.(1)Step3までに相当する）。リンク $l_{1}, l_{2}$ によって異なる遅れ時間は, それぞれダミーリン ク $D_{l_{1}}, D_{l_{2}}$ の旅行時間として評価する. この方法は, 最 短経路探索においては可能であろう。しかし，交通流の 計算においては，車両がダミーリンクを走行することに より, 他の下流側のリンクで生じている渋滞の延伸の影 響を受けなくなる。この場合, 車両の追い越しが生じ, First-In-First-Outの原則が守られない場合がある。そ のため, 本研究では, 起点ノードに対してのみダミーリ ンクとダミーノードを生成する図-5の方法により, 計算 対象ネットワークの構造を変換し, 数值計算を行う. 


\section{(3) Day-to-dayダイナミクス}

本研究では，石原ら ${ }^{5}$ と同样に「1日に複数台の車両 が前日の交通状態を基に同時に経路を変更する」という Day-to-dayダイナミクスを用いて動的利用者均衡配分 問題を定式化する．石原らりは，1日に経路変更を行う車 両を複数台と寸ることで，交通状態の定常状態を現実的 な時間で計算する方法を提案している. さらに，この研 究5では, 1日に経路変更する車両の台数を変化させ, 複 数の配分計算を実施し, 経路変更する台数を大きく設定 しすぎると交通状態の日々の変化が大きくなり，また， 多くの計算時間を要することを示している．これらを踏 まえ, 本研究では, 1日のうちに経路変更を行う台数を 石原ら ${ }^{8}$ が採用した「全車両の $5 \%$ の台数」とする.

本研究で扱う Day-to-dayダイナミクスは離散マルコ フ連鎖とみなすことができる，マルコフ連鎖とは，将来 の状態の条件付き確率分布が，現在の状態にのみ依存し， 過去のいかなる状態にも無関係である確率過程のことで ある．中でも，時間が離散的に推移するマルコフ連鎖を 離散マルコフ連鎖という. 現在の状態を $X_{n}$ とすると, 任意の状態が $j, i, i_{n-1}, \cdots, i_{0}$ で与えられたとき, 離散マル コフ連鎖は式(6)で表される推移確率行列 $p(i, j)$ を持つ。

$$
\begin{aligned}
& P\left(X_{n+1}=j \mid X_{n}=i, \mathrm{X}_{n-1}=i_{n-1} \cdots X_{0}=i_{0}\right) \\
& =P\left(X_{n+1}=j \mid X_{n}=i\right) \\
& =p(i, j)
\end{aligned}
$$

$p(i, j)$ が既約であり，かつ状態空間が有限であるとき, 定常分布が一つ存在することが知られている9 . 本研究 において, 当日の交通状態は前日の交通状態の夕に依存 して決定され，また，起こりうる交通状態の集合は離散 的, かつ有限である。したがって, 本研究で用いる Day-to-dayダイナミクスは，離散マルコフ連鎖とみな すことができ，これを計算することで交通状態の定常状 態を算出できるといえる.ここでは，1日の交通状態を マルコフ連鎖における1つの状態とみなしている.

Day-to-dayダイナミクスでは, 初期の交通状態を仮 定する必要がある，なお，本研究では，車両が初めてネ ットワークに配分をされる場合には「配分」という言葉 を用い，前日と異なる経路に車両を配分しなおす場合に は「再配分」という言葉を用いることとする．既往研 究4,5では, 各OD交通量に対して, 各リンクの自由流旅 行時間を用いた最短経路に全車両を配分寸ることで初期 の交通状態を求めている. しかし，この方法では，1本 の経路に車両が集中寸るために，初期の交通状態におけ る混雑が激しくなってしまう。これを避けるため, 本研 究では, 全車両について出発時刻の早い車両からIDを1 から順に与え，IDの順番で1台ずつ車両をネットワーク
に配分する方法で初期の交通状態を算出する．このとき， 車両を1台配分するごとに交通状態を更新し，次の車両 にはその交通状態に基づいて最短経路を選択させている。 以上の手順で全車両をネットワークに配分した状態を初 期の交通状態とする. その後, 個々の日において, 全車 両のうち $5 \%$ の車両を同時に再配分寸る. 再配分の対象 となった車両は, 前日の交通状態を前提として, 最短経 路を探索し, その経路に再配分される. この車両は, 次 に再配分の対象となるまでこの経路を使用しつづける.

一方，再配分の対象でなかった車両は，前日と同じ経路 をそのまま使用する。

交通状態が，どの程度収束しているかを確認するため， 再配分された車両の旅行時間の改善比（「経路変更後の 経路旅行時間」の「前日の経路旅行時間」に対する比) とその平均值を以下の式を用いて算出する.

$$
\begin{aligned}
& R_{s \in S}=\frac{T_{s, n}}{T_{s, n-1}} \\
& \bar{R}=\frac{\sum_{s \in S} \frac{T_{s, n}}{T_{s, n-1}}}{M}
\end{aligned}
$$

ここに, $R_{s}$ は再配分車両 $s$ の旅行時間改善比, $\bar{R}$ は全 再配分車両の旅行時間改善比の平均, $S$ は再配分の対 象車両集合, $T_{s, n}$ は $n$ 日目における車両 $s$ の旅行時間, $M$ は再配分車両の総台数とする. 再配分車両 $s$ の旅行 時間が経路変更後もほとんど変化しない場合，その車両 の旅行時間改善比 $R_{s}$ は 1 に近い值を示す．このとき，こ の車両 $s$ は, 最短経路に近い経路を選択しているといえ る. したがって, 再配分車両の旅行時間改善比の平均 $\bar{R}$ が1に近い值を示すとき，全ての車両が最短経路を走 行している状態に近い交通状態が実現しているといえる。 本研究では, 日々の旅行時間改善比を計算し, 交通状態 の収束の程度を確かめる.

渋滞の延伸を考慮することにより，グリッドロックが 生じる場合がある. グリッドロックとは, 渋滞により車 両が身動きの取れない状態になる現象である. 本研究で は，同じリンク先頭車両がリンクの流出判定時に, 流出 不可の判定をある一定回数連続して受けた場合をグリッ ドロックの発生と定義している. グリッドロックが一度 発生し，それを放置すると，その日の計算が終了せず， その日の各リンクの旅行時間を得られない. すると, 前 日の交通状態を必要とするマルコフ連鎖も計算できない. 本研究では, 特に渋滞の延伸が交通状態に及ぼす影響に ついて着目するため, 4章の数值計算では, グリッドロ ックが生じない計算条件を用いて，数值計算を実施する. 


\section{4. テストネットワークでの計算結果}

マルコフ連鎖による交通量配分の計算は, LeBlanc et al.ので用いられたSioux Falls Networkを対象に行う. このネットワークは，24個のノードと76本のリンクから なる. 本研究では, 車両の走行速度を $40 \mathrm{~km} / \mathrm{h}, 1 \mathrm{~km}$ あ たり100台車両が存在できると仮定し, LeBlanc et al. ${ }^{6}$ で与えられたリンク自由流旅行時間から各リンクの滞留 可能台数を算出した. 需要OD交通量は, グリッドロッ クが生じないようにLeBlanc et al. ${ }^{\circ} の O D$ 交通量を各々 同じ割合ずつ減らし，8875 台と設定した．また，10分間 で各OD交通量が全て出発するように各車両の出発時刻 を定める，計算は，渋滞の延伸を考慮した場合と考慮し なかった場合それぞれについて行う。

日々の交通状態の変化の定常性は, Heidelberger and Welch ${ }^{10)}$ によるマルコフ連鎖の定常性を統計学的に確か める手法を用いて検証する。 この検定では，帰無仮説を

「日々の交通状態の変化に定常性がある」とするもので ある.ここでは，1台あたりの平均遅れ時間を代表值と し，渋滞の延伸を考慮した場合と考慮しなかった場合の それぞれにおいて検定を行う。交通状態がある程度収束 している100日目〜2000日目を対象として代表值のデー 夕を20日ごとに渋滞の延伸を考慮した場合と考慮しなか った場合でそれぞれ抽出する．20日ごとのデータを用い る理由は，本配分計算では，1日に全車両の $5 \%$ の車両 が経路を変更するため, 連続する日の交通状態は変化が 小さく相関が強いといえるからである. したがって，本 検定では，デー夕間の相関をできる限り排除するため, 20日ごとのデータを抽出する（データ数は96個）。検定 の結果，有意水準 $\alpha$ が5\%の下で渋滞の延伸を考慮した 場合と考慮しなかった場合の $p$ 值はそれぞれ0.578, 0.305 となり, 帰無仮説は棄却されなかった。 このこと は, 日々の交通状態の変化に定常性がないとは積極的に 言えないことを意味している.

日々の全再配分車両の旅行時間改善比は, 式(7)に示 した方法で算出し，その平均值の推移を図-7に示寸. 渋 滞の延伸を考慮するしないに関わらず，旅行時間改善比 の平均值は 1 付近に収束しているため, 全ての利用者が 最短経路を選択している状態 (Nash均衡) に近づいて いることがわかる，また，いずれの場合も，旅行時間改 善比の平均が1付近を上下寸ることがある. 複数の車両 が同時に経路変更を行うため，再配分された車両が実際 にネットワークを走行するときには，前日の交通状態か ら変化している可能性がある. その交通状態の変化が, 多くの再配分車両の旅行時間をより短縮させるように作 用すると, 旅行時間改善比の平均は1を下回り, 逆に作 用すると1を上回ることになる，図-7に示すとおり，渋

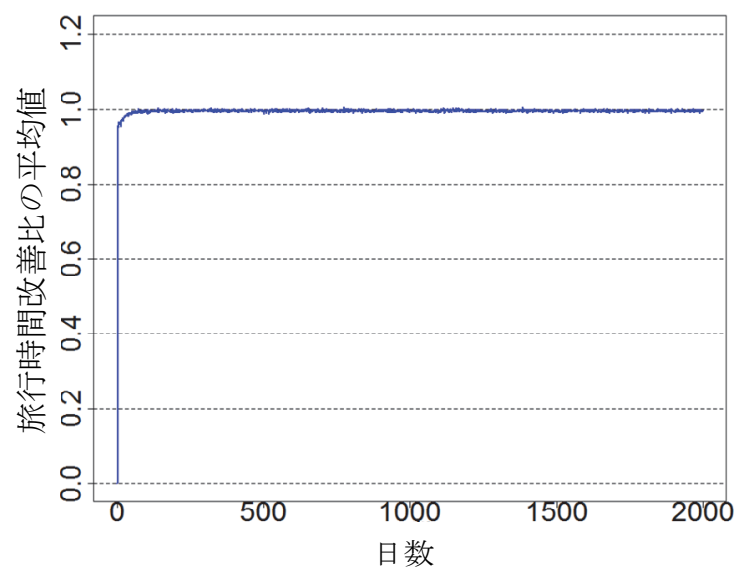

a) 渋滞の延伸なし

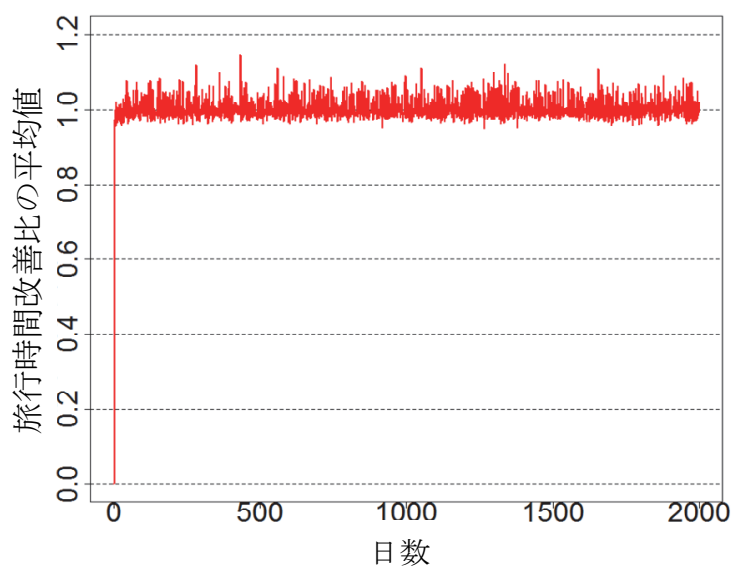

b) 渋滞の延伸あり

図-7 旅行時間改善比の平均值の推移

滞の延伸を考慮した場合は, 日々の旅行時間改善比の変 動が比較的大きいことから，渋滞の延伸を考慮しない場 合に比べて, 経路変更を行う車両が引き起こす交通状態 の変化の影響が大きいことが考えられる.これまでに示 した定常性の検証結果および旅行時間改善比の平均值が 1付近に収束した結果より，マルコフ連鎖によるDUEの 解法は渋滞の延伸を考慮した場合においても, 利用でき る可能性があるといえよう.

配分及び交通流の計算を2000日分繰り返した時の2000 日目の交通状態における各リンクの最大遅れ時間を図-8 に示寸. 最大遅れ時間が大きくなるほど, それに比例し て矢印の幅が広くなるように設定した. なお，矢印の方 向は車両の進行方向を示寸. 渋滞の延伸を考慮すること により，遅れ時間が増加するリンクがあることがわかる． また，その場合には，あるリンクの渋滞が，その隣接す るリンクに延伸しているように見える，例えば，図-8に おいて，ノード6から7に向かうリンクの渋滞がノード17 から6へ向かうリンク，そしてノード19から17へ向かう リンクに延伸しているように見受けられるだろう。

2000日目における各リンクの最大遅れ時間の平均值と 


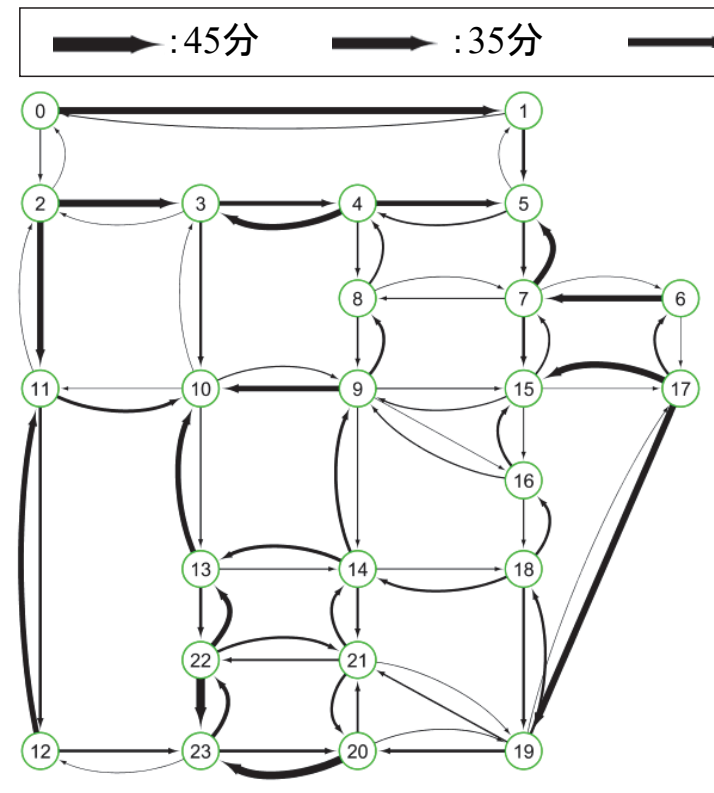

a) 渋帯の延伸なし

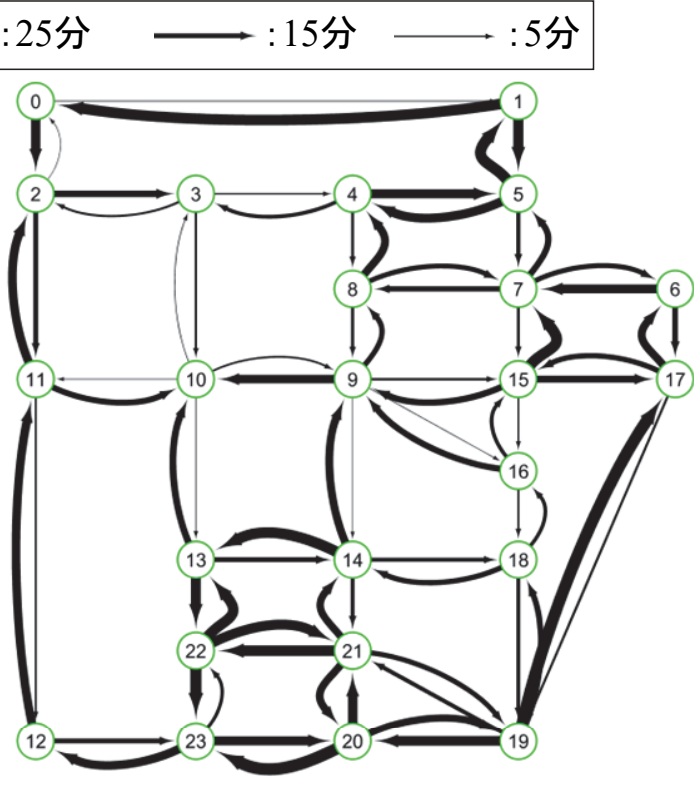

b) 渋滞の延伸あり

図-8 最大遅れ時間の比較 (2000 日目)

表-1 数值計算結果 (2000日目)

\begin{tabular}{lcc}
\hline & \multicolumn{2}{c}{ 渋滞の延伸 } \\
\cline { 2 - 3 } & なし & あり \\
\hline 最大遅れ時間の平均值 $(\mathrm{min} / \mathrm{link})$ & 7.92 & 19.16 \\
1台あたりの平均遅れ時間(min/veh) & 19.39 & 31.47 \\
\hline
\end{tabular}

1台あたりの平均遅れ時間を表-1に示す．渋滞の延伸を 考慮した場合は，各リンクの最大遅れ時間の平均值及び 1台あたりの平均遅れ時間の両方が渋滞の延伸を考慮し なかった場合に比べて大きいことがわかる.

啮滞の延伸を考慮することでリンクの混雑が増加する ことを統計学的に明らかにする. 各リンクの最大遅れ時 間の平均值を代表值として用いる. 先の検定と同様に 100日目〜2000日目を対象として，20日ごとに代表值を 渋滞を考慮した場合と考慮しなかった場合でそれぞれ抽 出し（データ数は96個），母平均の差の検定を行う。2 つのデータ集合間の等分散は仮定せず，有意水準 $\alpha$ は $5 \%$ と設定し, Welchのtの片側検定をRプログラムで行 う。検定の結果， $p$ 值は $2.2 \times 10^{-16}$ となったため，渋滞 の延伸を考慮した場合は考慮しなかった場合に比べて各 リンクの最大遅れ時間が大きいといえる.

\section{5. 結論および今後の課題}

本研究では，交通流パターンの日々の調整過程である Day-to-dayダイナミクスを離散マルコフ連鎖により記 述することで，動的利用者均衡配分問題の均衡解あるい は定常状態を求める解法において, 既往研究4)5)では考慮
されていない「渋滞の延伸」を考慮できる交通流モデル を構築し，適用することでマルコフ連鎖の解法の妥当性

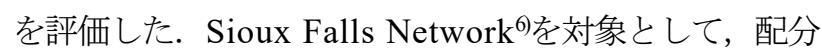
計算を2000日分行った. 日々の交通状態の変化の定常性 の検証では，定常性がないとは積極的には言えないとい う結果が得られた. また, 渋滞の延伸を考慮した場合に おいても，考慮しない場合と同様に全ての利用者が最短 経路を選択している状態（Nash均衡）に近い状態に収 束することが明らかとなった。 したがって, 渋滞の延伸 を導入した場合でも，マルコフ連鎖によるDUEの解法は 利用できる可能性があるといえる. 一方で, 渋帯の延伸 を考慮した場合は，考慮しなかった場合に比べて，日々 の交通状態の変化が大きいことから，渋滞の延伸は旅行 時間の信頼性を悪化させると言えよう. 加えて, 同じ OD交通量を用いた場合でも，渋滞の延伸モデルの有無 によって, 各リンクの遅れ時間に大きな差が生じたこと から，渋帯の延伸はネットワークの評価を行う際に考慮 すべきであるといえる.

今後の課題について述べる. 本研究で用いたリンク旅 行時間モデルではリンク内の滞留台数の上限を定めただ けであり，Q-K特性を正しく与えていないため，リン ク内でのショックウェーブを正しく表現できていない. リンク内での渋滞の延伸を㛜密に表現するためには適切 なQ-K特性を導入することが必要である。また，本研 究では，グリッドロックが生じない場合について数值計 算を行った。しかし，渋帯の延伸を考慮すると，グリッ ドロックが生じる場合がある.グリッドロックが生じた 場合は，Day-to-dayダイナミクスの計算が継続できな 
い. ただし, 既往研究ではシミュレーション中にグリッ

ドロックの発生を許容しているものもある11). 本研究の

方法論についても, グリッドロックの発生を考慮した上

でのさらなる検討が必要であろう。また, 繰り返し計算

に伴って多大な計算量が要求されるため, さらに大規模

かつ複雑なネットワークを対象に計算を行うためには,

計算を並列化し計算速度の向上を行う必要があろう。

\section{参考文献}

1) Kuwahara, M. and Akamatsu, T. : Dynamic equilibrium assignment with queues for a one-to-many OD Pattern, Transportation and Traffic Theory: Proceedings of the 12th International Symposium on the Theory of Traffic Flow and Transportation, C. F. Daganzo (Ed.), pp. 185204, 1993.

2) 井料隆雅 : 車両を離散化した動的交通量配分問題の Nash 均衡解の解法, 土木学会論文集 D3, Vol. 67, No. 1, pp. I_70-I_83, 2011.

3) Iryo, T. : Properties of dynamic user equilibrium solution: existence, uniqueness, stability, and robust solution methodology, Transportmetrica B: Transport Dynamics, Vol. 1, No. 1, pp. 52-67, 2013.

4) 石原雅晃, 井料隆雅：マルコフ連鎖による動的ネッ トワーク交通量配分, 土木学会論文集 D3, Vol. 71, No. 5,pp. I_503-I_509, 2015.

5) 石原雅晃, 藤原龍, 井料隆雅 : 多数ケースの動的交
通量配分の数值計算の高速化, 第 13 回 ITS シンポジ ウム 2015, CD-ROM, 2015.

6) LeBlanc, L. J., Morlok, E. K. and Pierskalla, W. P. : An efficient approach to solving the road network equilibrium assignment problem, Transportation Research, Vol. 9, pp. 309-318, 1975.

7) Lo, H. K. and Szeto, W. Y. : A cell-based variational inequality formulation of the dynamic user optimal assignment problem, Transportation Research Part B, Vol. 36, No. 5, pp. 421-443, 2002.

8) 石原雅晃, 福田和輝, 井料隆雅 : 交通流シミュレー ションによる動的利用者均衡配分の高速計算, 情報 処理学会 第 78 回全国大会講演論文集, Vol. 1, pp. 371-372, 2016.

9) Durrett, R. : Essentials of Stochastic Processes, Dordrecht: Springer New York, 2012（ドゥレット R, 今野紀雄・ 中村和敬・曾雌隆洋・馬霞（訳）, 確率過程の基礎, 東京：シュプリンガー・フェアラーク東京，2015）。

10) Heidelberger, P. and Welch, P. : Simulation run length control in the presence of an initial transient, Operations Research, Vol. 31, No. 6, pp. 1109-1144, 1983.

11) Mahmassani, H. S., Saberi, M. and Zockaie, A. : Urban network gridlock: Theory, characteristics, and dynamics, Transportation Research Part C: Emerging Technologies, Vol. 36, pp. 480-497, 2013.

(2017. 2. 24 受付)

\section{DYNAMIC USER EQUILIBRIUM ASSIGNMENT BY MARKOV CHAIN INCLUDING QUEUE SPILLBACK}

\section{Kazuki FUKUDA, Takamasa IRYO, Junji URATA and Masaaki ISHIHARA}

Several solution methods have been proposed to calculate a user equilibrium solution in a dynamic traffic network. Finding a stationary distribution of a Markov chain that model drivers' day-to-day route choice behaviours can be an alternative to solving an equilibrium solution. In this paper, we adopted a physical-queue model because it can capture the queue spillback phenomenon, which can provide a more realistic result, and use the Markov chain methodology. Using the Sioux Falls network, we observed that a stationary distribution of the Markov chain can be calculated. In addition, we found that the arising congestions on the network using a point-queue model and a physical-queue model were different. 